\title{
Ірина Лебедєва
}

кандидат фізико-математичних наук, доцент, доцент кафедри вищої математики й економіко-математичних методів, Харківський національний економічний університет ім. С. Кузнеця; Харків, Україна

ORCID: 0000-0002-0381-649X

E-mail: irina.lebedeva@hneu.net

\section{Лариса Норік}

кандидат економічних наук, доцент, доцент кафедри вищої математики й економіко-математичних методів, Харківський національний економічний університет ім. С. Кузнеця; Харків, Україна

ORCID: 0000-0002-7077-1260

E-mail: larisa.norik@gmail.com

\section{Степан Лебедсв}

старший викладач кафедри вищої математики й економіко-математичних методів, Харківський національний економічний університет

Iм. С. Кузнеця; Харків, Україна

ORCID: 0000-0001-9617-7481

E-mail: stepan.lebedev@hneu.net

\section{ЕЛЕМЕНТИ ІНТЕРАКТИВНИХ ТЕХНОЛОГІЙ У ВИКЛАДАННІ ДИСЦИПЛІН МАТЕМАТИЧНОГО СПРЯМУВАННЯ}

Анотація: розглянуто можливості, які надає застосування інтерактивних технологій під час викладання дисциплін математичного спрямування, що $є$ обов'язковими в процесі підготовки майбутніх фахівців 3 економіки та менеджменту. Наведено приклади позитивного впливу використання технології “перевернутого” класу на сприйняття нового матеріалу в умовах онлайн-навчання, а також елементів гейміфікації - на формування у студентів компетентностей щодо можливостей використання математичного апарату у майбутній професійній діяльності.

Ключові слова: дисципліни математичного спрямування, онлайн-навчання, STEMосвіти, хмарна платформа Zoom, віртуальне навчальне середовище Moodle, технології “перевернутого” навчання, гейміфікація.

\section{Irina Lebedeva}

candidate of physical and mathematical sciences, associate professor, associate professor of the department of higher mathematics and economic and mathematical methods of S. Kuznets

Kharkiv National University of Economics; Kharkiv, Ukraine

E-mail: irina.lebedeva@hneu.net

( Ірина Лебедєва, Лариса Норік, Степан Лебедєв, 2021 


\section{Larisa Norik}

candidate in economics, associate professor, associate professor of the department of higher mathematics and economic and mathematical methods of S. Kuznets

Kharkiv National University of Economics; Kharkiv, Ukraine

E-mail: larisa.norik@gmail.com

\section{Stepan Lebedev}

senior lecturer of the department of higher mathematics and economic and mathematical methods of S. Kuznets Kharkiv National University of Economics; Kharkiv, Ukraine E-mail: stepan.lebedev@hneu.net

\section{ELEMENTS OF INTERACTIVE TECHNOLOGIES IN THE TEACHING OF MATHEMATICAL DIRECTIONS}

Abstract: examines the opportunities that are provided through the using of interactive technologies in the teaching of disciplines of the mathematical cycle. These disciplines are basic in the training of future economists and managers. Examples of the positive impact of using the "flipped" classroom technology on the perception of new material in the context of online learning are given. And also praxis of using elements of gamification for the formation of students' competencies related to the use of the mathematical apparatus in their future professional activities are demonstrated.

Key words: mathematics disciplines, online learning, STEM-education, Zoom cloud platform, Moodle virtual learning environment, flipped classroom technologies, gamification.

\section{Ирина Лебедева, Лариса Норик, Степан Лебедев}

\section{ЭЛЕМЕНТЫ ИНТЕРАКТИВНЫХ ТЕХНОЛОГИЙ В ПРЕПОДАВАНИИ ДИСЦИПЛИН МАТЕМАТИЧЕСКОГО ЦИКЛА}

Аннотащия: рассмотрены возможности, которые появляются благодаря использованию интерактивных технологий в процессе преподавания дисциплин математического цикла. Эти дисциплины являются обязательными при подготовке будущих экономистов и менеджеров. Приведены примеры позитивного влияния использования технологии "перевернутого" класса на восприятие нового материала в условиях онлайн-обучения, а также элементов геймификации - на формирование у студентов компетентностей, связанных с применением математического аппарата в будущей профессиональной деятельности.

Ключевые слова: дисциплины математического цикла, онлайн-обучение, STEMобразование, облачная платформа Zoom, виртуальная обучающая среда Moodle, технологии “перевернутого” обучение, геймификация.

\section{Irina Lebedeva, Larisa Norik, Stepan Lebedev}

An extended abstract of the paper on subject of:

\section{"Elements of interactive technologies in the teaching of mathematical directions"}

Problem setting. In recent decades, there have been growing disparities between the level of Ukrainian education and the demands that society places on the development of human capital. Thus, there is a need to transform the education system in order to ensure its quality at all levels, from preschool to higher education and adult 
education. At the level of higher education, the goal of the reform is to create a competitive system of vocational education, which is able to meet the needs of both the labor market and the professional realization of the individual. One of the factors that can ensure the success of Ukraine's development, its transition to a post-industrial society based on the knowledge economy, is the integration of ICT in the learning process and, thanks to this, the widespread introduction of innovative training technologies. This is especially to the purpose in the context of the transition to onlyne learning due to the spread of COVID-19.

\section{Recent research and publica- tions analysis.}

The introduction of ICT in the educational process opens up a number of opportunities to improve the quality of education in general and higher education in particular, but also sets new challenges. First of all, it creates conditions for free access to educational resources at any time and in any place. But online learning is productive, and its effectiveness is high only when the student has internal motives to learning. Thus, the teacher has a task not only to create quality content, but also to organize the learning process so that the student was interested in this discipline, so that this learning was persistent. And the use of IT technologies opens up new opportunities for this. In the field of economics and management, game techniques are the most acceptable for increasing student activity. They allow you to create models of situations that a student may face in future professional activities. IT technologies make it possible to apply elements of gamification both in the format of individual communication and in the course of group or frontal-collective work. However, such techniques are mainly used either at the primary school or, conversely, in adult business education.

Paper objective. The purpose of this article is to analyze, systematize and generalize the experience of introducing interactive teaching methods using ICT in the training of future specialists in economics and management on the example of mathematical disciplines' cycle.

Paper main body. The authors of the article tested the effectiveness of interactive methods on the example of teaching the disciplines "Applied Mathematics" and "Probability Theory and Mathematical Statistics", which are basic for students of $S$. Kuznets KNUE. 180 first-year students took part in the experiment. Elements of interactive technologies such as gamification and the flipped classroom were used to intensify the online learning process. In the control groups, teaching was performed according to the standard method.

Implementation of elements of interacttive technologies was carried out on the basis of modular objectoriented dynamic learning environment, which is course management system Moodle, and also with using the service Zoom, which is standard software application for online video and audio conferencing, collaboration, chat, and webinars across mobile devices, desktops, and telephones.

Adaptation was carried out in six steps. In the first step, the diagnosis of the initial level of knowledge was carried out, which turned out to be the same for the students of the experimental and control groups. In the second step, the target audience was set up for teamwork. The third step involved acquainting students with the structure of the educational process and the tasks they must perform in the learning process. In the fourth step, students received information about methods of encouragement. The fifth step involved the division of educational activities into separate cycles and the development of elements of interactive techniques for each cycle. The sixth step in the introduction of interactive elements in the learning process is to develop tools that allow students to independently monitor the level of their academic achievements.

Conclusions of the research. Analysis of the research results suggests that 
МАЙСТЕРНОСТІ МАЙБУТНІХ ФАХІВЦІВ

for mathematical disciplines the use of elements of interactive technologies in the educational process is an effective means of increasing motivation to learn and the quality of learning in general. This is due to

Постановка проблеми у загальному вигляді та іiі зв'язок із важливими науковими чи практичними завданнями. Однією із знакових подій 2000 року, що є завершальним роком II міленіуму, було затвердження Генеральною Асамблеєю ООН “Декларації тисячоліття” [29], у якій були означені цінності, принципи і ключові чинники глобального процесу сталого розвитку. Визнаючи необхідність за безпечення цього процесу, Україна, як i інші країни-члени ООН, розробила стратегію його реалізації. Серед цілей, адаптованих для України на 2015-2030 роки, однією з провідних вважається якість освіти. Так, серед 17 стратегічних цілей, які означила для себе Україна, забезпечення якості освіти посідає 4 місце [16, с. 32].

Показники якості вищої освіти в Україні є доволі неоднорідними. Основною проблемою сучасної системи української освіти, що потребує вирішення, $\epsilon$ невідповідність підготовки кваліфікованих кадрів ані потребам особи, ані потребам національної економіки та суспільства в цілому [5]. Протягом останніх десятирічь спостерігається зростання розбіжностей між рівнем української освіти і тими вимогами, які ставить суспільство щодо розвитку людського капіталу, тоді як місія вищої освіти полягає саме у створенні умов для інноваційного розвитку України через підготовку висококваліфікованих фахівців, формування та поширення знань, розбудову інтелектуального, соціального і духовного капіталу суспільства, здатного відповідати на виклики майбутнього [14, c. 35]. Отже, виникає потреба у трансформації системи освіти 3 метою забезпечення iï якості на всіх рівнях, починаючи 3 дошкільної й до вищої освіти та освіти дорослих. the growing interest of students in the subject and understanding of how mathematical tools can be used in the professional activities of future professionals in economics and management.

Провідним чинником, спроможним забезпечити успішність сталого розвитку України, іiі перехід до постіндустріального суспільства, що базується на економіці знань, $€$ інтегрування інформаційнокомунікаційних технологій (IКT) у процес навчання i, спираючись на їхні можливості, широке впровадження інноваційних технологій i новітніх трендів діджиталізації. Особливої актуальності застосування ІКТ набуває в сучасних умовах, коли у зв'язку з карантинними заходами, причиною яких є поширення COVID-19, виникає необхідність у забезпеченні якості освітніх послуг при переході на дистанційну форму навчання. Цифровізації освіти i науки навіть була присвячена окрема сесія на Всеукраїнському форумі "Україна 30. Освіта і наука" [2].

Аналіз останніх досліджень і публікацій, у яких започатковано розв'язання цієї проблеми і на які спираються автори. Сучасні освітні тенденції як в Україні, так і в усьому світі визначаються, передусім, потребами економіки. Теперішний етап розвитку суспільства в цілому розглядається як перехід від індустріального до постіндустріального стану [20]. Четверта промислова революція [26] і ступінь реалізації цього переходу визначається тим, у якій мірі здійснюється трансформація знань у безпосередній фактор виробництва. Отже, якість людського капіталу стає провідним ресурсом розвитку країни. За даними, що наведені у звіті Всесвітнього економічного форуму The Global Competitiveness Report 2019 [31], за показником "Навички", що поряд 3 показником “Здоров'я” є оцінкою людського капіталу, у 2019 році Україна посіла 44 місце зі 141 країни, серед яких проводилося дослідження. Таке, достатньо високе, місце у 
рейтингу визначили показники "Критичне мислення у навчанні” (31 місце) та "Співвідношення учнів і вчителів у початковій освіті” (33 місце). Навпаки, за показниками, що характеризують стан вищої освіти, позиції України є значно гіршими. Так, за показниками “Обсяг кваліфікованого персоналу" та “Якість професійного навчання" Україна посіла 65 місце у рейтингу. Не дуже високим $є$ i показник "Цифрові навички активного населення" - лише 56 місце. Щодо вміння застосовувати набуті знання у практичній діяльності, яка пов'язана із впровадженням інноваційних технологій, то тут ситуація така: за показником “Ділова активність” Україна посіла лише 85 місце. Отже, спостерігається розрив між обсягом теоретичних знань i їхньою якістю, а також вмінням впроваджувати ці знання до професійної діяльності. У зв'язку 3 цим виникає потреба не просто у реформуванні освіти, а у зміні освітньої парадигми. Звернемося до досвіду економічно-розвинутих країн i розглянемо ті новітні технології, які вони застосовують для забезпечення якості професійної освіти.

У сучасній теорії управління стосовно постановки завдання існує термін SMART, тобто ціль, якої необхідно досягти, повинна бути конкретною (Specific), придатною для вимірювання (Measurable), досяжною (Achievable), відповідною (Rele-vant), обмеженою у часі (Time-bound). Такий саме підхід зараз реалізують і в управлінні знаннями. Відбувається перехід від e-learning до Smart education [15]. Омонімічний акронім SMART, що визначає розумну мету, у цьому випадку розкривають як Самокерованість, Мотивація, Адаптація, Ресурсозабезпечення та Технологічність. Смарт-освіту, смарт-технології розглядають як нову парадигма сучасної системи освіти [3].

Підгрунтям, на якому базується більшість сучасних освітніх реформ, слугують IКТ, що останнім часом набу- вають всеосяжного впровадження. Зміни, які завдяки цьому відбуваються у суспільному житті, є на стільки суттєвими, що їх визначають як діджиталізацію, тобто цифрову трансформацію суспільства [18]. Важливість впливу ІКТ на всі сфери суспільного життя підтверджує той факт, що одним із показників, який входить до складу нового Індексу глобальної конкурентоспроможності 4.0, є цифрові навички активного населення. Статистичні дані свідчать [21] про швидке зростання обсягу послуг на світовому ринку енавчання. Так, за період з 2017 по 2019 роки світовий ринок електронного навчання виріс на $200 \%$ і складав 250 млрд доларів. Очікується, що до 2025 року він перевищить 300 млрд доларів. I ці прогнози були зроблені тоді, коли про COVID-19 ще нічого не було відомо. Зрозуміло, що в умовах пандемії слід очікувати на перевищення цих цифр.

Запровадження IКТ у навчальному процесі відкриває цілий ряд можливостей щодо поліпшення якості освіти взагалі й вищої освіти зокрема, але й ставить нові завдання. По-перше, це створює умови вільного доступу до освітніх ресурсів, у будь-який час, у будь-якому місці. Абревіатура EdTech (Education Techno$\operatorname{logy})$ - це не тільки технологія, що передбачає впровадження IT-інструментарію у навчання [23; 25], але й розвинена мережа компаній, які розробляють освітні технології [22]. Серед таких компаній $є$ й українські. Огляд EdTech-стартапів наведено в роботі [11]. Завдяки можливостям, які надають такі стартапи, викладачі мають змогу використовувати вже готовий освітній контент або самі розробляти мультимедійні курси та знімати відео-лекції, які потім студенти вивчатимуть самостійно у зручному для них темпі. Це i раніше мало велике значення для забезпечення якісного дистанційного навчання студентів заочної форми навчання. А протягом 2020/2021 навчального року та другої половини 
МАЙСТЕРНОСТІ МАЙБУТНІХ ФАХІВЦІВ

2019/2020 навчального року, коли у зв'язку з поширенням COVID-19 діяли суворі карантинні обмеження, саме застосування інформаційно-комунікаційних технологій дало можливість проводити онлайн-заняття зі студентами очної форми навчання відповідно до діючого розкладу. Крім того, зараз у світі існує чимало освітніх онлайн-платформ 3 відкритим доступом, що пропонують великий перелік програм навчання (обсягом від 1 до 6 кредитів за шкалою ECTS) для різних рівнів освіти. За цими програмами до проведення занять залучають професорів провідних університетів та експертів світового рівня, а також за результатами навчання надається можливість отримати сертифікат [27]. Подруге, онлайн-заняття $є$ продуктивними, i їхня ефективність висока лише тоді, коли у студента існують внутрішні мотиви, особистісне налаштування на навчання. Отже, перед викладачем постає завдання не тільки створити якісний контент, але й так організувати процес навчання, щоб студенту було цікаво вивчати саме цю дисципліну, щоб це навчання було наполегливим. I застосування IT-технологій відкриває для цього нові можливості. Попередній досвід свідчить [8], що організація онлайн-навчання 3 використанням таких освітніх платформ, як Moodle, а також хмарної платформи Zoom для проведення відео та аудіо конференцій і вебінарів дає можливість більш щільно взаємодіяти зі студентами, у яких виникала потреба у такому спілкуванні. Як наслідок, успішність тих студентів, які були налаштовані на навчання, підвищується. Проте існує й інша частина студентів, успішність яких в умовах онлайн-навчання погіршилась. У таких студентів низька або зовсім відсутня здатність до самоконтролю. Коли заняття проводилися в аудиторії, такі студенти були присутні на них лише формально, але не були налаштовані на роботу. Для того, щоб спонукати їх до співпраці, щоб спрямувати їхні зусилля на засвоєння матеріалу, у викладача були такі важелі впливу, як викликати їх до дошки або давати завдання для самостійного розв'язання. Отже, у певному сенсі карантинні обмеження відіграли роль каталізатора для пошуку шляхів вдосконалення інтерактивних технологій навчання, застосування яких стає можливим саме завдяки IКТ.

Курс на розвиток інтерактивних технологій є загальним трендом вдосконалення онлайн-навчання, але особливо гостро ця проблема постає при вивченні дисциплін математичного спрямування, оскільки саме природничо-математична освіта повинна стати однією із складових державної політики, шо спрямована на розвиток людського капіталу i забезпечення конкурентоспроможності національної економіки [6]. Концепція STEMосвіти (Science, Technology, Engineering and Mathematics) передбачає поєднання міждисциплінарних знань та креативного підходу до їх використання при розв'язанні реальних проблем 3 подальшою реалізацією у професійній діяльності. У галузі технічних наук втілення концепції STEM-освіти стає можливим завдяки створенню спеціальних центрів (лабораторій), застосуванню робото-технічних систем, вимірювальних комплексів, 3Dпринтерів тощо. Усе це можна реалізовувати завдяки інструментарію EdTech.

У галузі економіки та менеджменту найбільш прийнятними $є$ ігрові методики [19], що дозволяє створювати моделі ситуацій, з якими студент може стикатися у майбутній професійній діяльності, або окремих моментів таких ситуацій. IT-технології дають можливість застосовувати елементи гейміфікації як у форматі індивідуального спілкування, так і в ході групової або фронтально-колективної роботи. Вважають [25], що застосування ігрових елементів у е-навчанні здатне на $89 \%$ підвищити його ефективність. Слід також зауважити, що реалізація бізнессимуляції в онлайн-форматі стає в нагоді в умовах карантинних обмежень, оскільки 
такі тренінги є альтернативою виробничої практики. Також в якості техніки, яку доцільно використовувати під час підготовки майбутніх економістів та менеджерів, можна запропонувати “перевернуте" навчання [24], коли за певною темою основний матеріал студент вивчає самостійно, а потім у групі спільно 3 викладачем відбувається обговорення цього матеріалу. Такий підхід формує у студентів навички самоосвіти, сприяє розвитку критичного мислення.

Вплив інформаційно-комунікаційних технологій на формування професійних компетентностей у різних предметних галузях знань вже давно став об'єктом теоретичних і експериментальних досліджень. Внеском до впровадження ІТ-технологій в освітній процес слід вважати роботи таких вітчизняних вчених і педагогів-практиків, як Жалдак М. [4], Коваль Т. [7], Н. Морзе [10], О. Пометун [12], С. Семерікова [13], Ю. Триуса [28] та багатьох інших. Однак щодо використання IКТ в організації навчальної діяльності закладів вищої освіти, то практичний досвід в основному накопичено щодо викладання іноземної мови [17], а також дисциплін математичного спрямування, але в основному для студентів інженерних спеціальностей [13; 28].

Виділення не вирішених раніше частин загальної проблеми, котрим присвячується дана стаття. Достатньо розроблені й широко застосовуються у навчальному процесі інтерактивні технології, що базуються на використанні IКТ, хоча такі техніки, як гейміфікація, в основному застосовуються або на рівні початкової школи [9], або навпаки, у бізнес-освіті дорослих [1, с. 269]. Однак недостатність розробок та нестаток прикладів запровадження елементів гейміфікації та інших інтерактивних технологій під час викладання обов'язкових дисциплін математичного спрямування у закладах вищої освіти для студентів економічних спеціальностей обумовлюють необхідність досліджень та визначають актуальність даної роботи.

\section{Формування цілей статті}

(постановка завдання). Мета статті полягає в систематизації та узагальненні досвіду запровадження елементів інтерактивних технологій в процесі підготовки майбутніх фахівців 3 економіки та менеджменту на прикладі дисциплін математичного циклу.

Виклад основного матеріалу дослідження 3 повним обгрунтуванням отриманих наукових результатів. У весняному семестрі 2020/2021 навчального року авторами статті було апробовано запровадження інтерактивних елементів у навчальному процесі окремих обов'язкових дисциплін математичного циклу, які викладаються кафедрою вищої математики й економіко-математичних методів у ХНЕУ ім. С. Кузнеця.

Гіпотеза, яка підлягала перевірці у цьому дослідженні, сформульована таким чином: використання елементів інтерактивних технологій під час викладання дисциплін математичного спрямування дозволить нівелювати труднощі, що постають перед студентами під час навчання, i, відповідно, підвищити рівень зацікавленості студентів до вивчення математичних дисциплін. Як наслідок, очікується підвищення якості набутих знань, що проявляється у здатності застосовувати математичний апарат до розв'язання ситуаційних та евристичних завдань $з$ економічним підгрунтям.

Реалізація елементів інтерактивних технологій здійснювалася на базі онлайнсервісу Zoom для проведення відеоконференцій та модульного об'єктноорієнтованого динамічного навчального середовища - системи електронного навчання Moodle LMS, які виявилися активно затребуваними у період дії карантинних обмежень, пов'язаних 3 пандемією COVID-19.

Усього в експерименті брало участь 180 студентів першого курсу: дві групи спеціальності "Видавництво та поліграфія", дві групи спеціальності "Міжнародна економіка" та п’ять груп студентів спе- 
ціальності “Комп’ютерні науки”. У цих групах під час викладання дисциплін математичного спрямування використано такі елементи інтерактивних технологій, як гейміфікація та "перевернутий” клас, а в інших (контрольних) групах застосовано стандартний підхід до викладання навчального матеріалу. Використання двох різних підходів дозволить порівняти їхню ефективність.

Вирішення освітніх завдань під час вивчення математичних дисциплін передбачає послідовне проходження таких стадій: діагностуюча, формуюча та контрольна. На стадії діагностики проводиться визначення початкового рівня знань і вмінь студентів; на формуючій безпосередньо здійснюється робота щодо формування професійних компетентностей майбутніх фахівців; на контрольній оцінюється ефективність проведеної роботи. На кожній із цих стадій автори перевіряли ефективність застосування елементів інтерактивних технологій $\mathrm{y}$ навчальному процесі.

У ході розроблення навчальнопізнавальних інтерактивних елементів на онлайн-сторінці лектора 3 певної навчальної дисципліни (експеримент проводився за дисциплінами "Прикладна математика" i "Теорія ймовірностей та математична статистика") були адаптовані шість етапів структури гейміфікації до процесу навчання [30], які, на погляд авторів, $\epsilon$ одним із варіантів впровадження інтерактивних технологій до навчального процесу.

На першому етапі було визначено мету впровадження елементів інтерактивних технологій, що полягає у підвищенні рівня засвоєння студентами теоретичних положень та практичних прийомів розв'язання завдань за окремою навчальною дисципліною. Діагностика базових знань із математики на рівні програми середньої школи показала, що початковий рівень знань у студентів $\epsilon$ приблизно однаковим i складає в середньому 72 бали за 100 бальною шкалою. Такий рівень є не дуже високим.
Також у окремих студентів спостерігалась відсутність мотивації до вивчення математики і низька успішність. У ході ознайомчого спілкування зі студентами було відзначено, що не всі вони активні, не завжди розуміють корисність звернення до додаткових джерел для отримання інформації, не прагнуть до взаємодії один із одним для кращого розуміння предмету, відчувають певні труднощі i виявляють скутість, відповідаючи на питання викладача. Це говорить про те, що необхідна робота щодо формування інтересу до навчання, без якого неможливо досягти високих результатів.

На другому етапі було здійснено опис цільової аудиторії. Так, учасниками експерименту щодо впровадження елементів інтерактивних технологій у навчальний процес стали студенти, які $\epsilon$ достатньо обізнаними у цифровому віртуальному просторі. Соціальні мережі, Інтернет, комп'ютерні програми i таке інше - все це $\epsilon$ звичними для них ресурсами. I це необхідно враховувати під час створення структури освітнього контенту. Оскільки діагностичне спілкування виявило окремих лідерів серед студентів, було запропоновано кожному 3 них сформувати команди з 7-8 студентів, щоб вони охоплювали всіх студентів у межах однієї академічної групи. У подальшому ці команди змагатимуться за найвищий результат у навчанні.

На третьому етапі описано цільову поведінку, а саме: студенти мають отримувати винагороду за виконання певних видів робіт, наприклад, вивчення навчальних матеріалів за означеною темою, своєчасне виконання домашніх завдань, лабораторних робіт, успішне виконання контрольних робіт, складання колоквіумів тощо. Порядок оцінювання рівня засвоєння навчального матеріалу визначався Робочим планом навчальної дисципліни, який містить опис системи накопичування балів за 100-бальною шкалою (табл. 1).

Оскільки інтерактивний освітній процес - це абсолютно новий для 
студента вид діяльності, необхідно надати чіткі інструкції щодо участі в ньому. Так, подібно до того, як у будь-якій грі існує інструкція, що містить правила гри, аналогічний засіб слід використовувати під час навчання, щоб уникнути непорозумінь і можливих труднощів. Тому інформація щодо структури та графіку оцінювання завдань стає для студента вказівником того напряму дій, якого слід дотримуватися для досягнення цілі навчання та регулятором часу, необхідного для виконання певного виду робіт.
На четвертому етапі було визначено формат системи заохочень. Платформою підвищення зацікавленості студентів до навчання стає конкретна онлайн-сторінка лектора певного навчального курсу в Moodle LMS. Структура будь-якого навчального курсу має або тижневий, або тематичний формат i складається 3 корисних матеріалів за навчальним курсом, 3 посилань на тематичні ресурси та рекомендовані електронні навчально-методичні посібники, форуму новин, де мають обгово-

Таблиия 1

\section{Типовий графік оцінювання за навчальною дисципліною математичного циклу (бали на тиждень)}

\begin{tabular}{|c|c|c|c|c|c|}
\hline Види робіт / навчальний тиждень & $\stackrel{i}{a}$ & $\begin{array}{l}\infty \\
b \\
b\end{array}$ & $\stackrel{2}{2}$ & $\frac{b}{ \pm}$ & $\infty$ \\
\hline Домашнє завдання (ДЗ) & 2 & 2 & 2 & 2 & - \\
\hline Лабораторна робота (ЛР) & 2 & 4 & 4 & 2 & - \\
\hline Самостійна творча робота (CР) & - & - & 8 & - & - \\
\hline Контрольна роботи (КР) & 6 & - & 6 & 6 & - \\
\hline Колоквіум & - & 7 & - & 7 & - \\
\hline Іспит & - & - & - & - & 40 \\
\hline
\end{tabular}

рюватися питання студентів, а також опції особистих повідомлень, які дозволяють у разі необхідності отримати студенту консультаційну підтримку.

П'ятим етапом було розроблення циклів діяльності. Кожен вид заняття та роботи студента доцільно довести до інтерактивного формату, ввести елементи гри. Спочатку вони мають ознайомитися 3 теоретичним матеріалом (уважно слідкувати за викладанням матеріалу під час онлайн лекції в Zoom, конспектувати та опрацьовувати матеріали презентацій, навчальних та методичних посібників за конкретною темою навчальної дисципліни). Інтерактивний компонент вводиться на лекції, де присутні всі групи навчального потоку, що беруть участь в експерименті. За допомогою вбудованої в інтерфейс Zoom інтерактивної дошки повідомлень або демонстрації екрану лектор надає командам ілюстрацію завдання (графік, таблицю, числові масиви тощо) та формулює проблемне питання, що пов'язане 3 темою лекції. Студентам виділяється невеликий проміжок часу на обговорення, згодом представник від кожної команди у режимі чату дає обгрунтовану відповідь. Завдяки опції налаштування в Zoom “Дозволити коментарі учасників" студенти мають можливість доповнювати матеріал на екрані. Наприклад, за темою "Наближені обчислення” 3 навчальної дисципліни "Прикладна математика" надається графік взаємного розташування двох нелінійних функцій $f_{1}(x)=6^{x}, f_{2}(x)=x^{2}+3 \quad$ та пропонується на конкретному прикладі довести доцільність використання методу бісекції для розв'язання рівняння 
$f_{1}(x)-f_{2}(x)=0$. Команда, яка швидше за всіх надає правильну відповідь і повністю iii обгрунтовує, отримує гейм-бал. Протягом семестру гейм-бали накопичуються за кожним змістовим модулем навчальної дисципліни i конвертуються у частку оцінки за колоквіум.

Ще одним інтерактивним компонентом є самодіагностика. Вона проводиться за бажанням кожного студента у форматі проходження тестів із теоретикних питань за певною темою. Результати тестування за кожною темою теж накопичуються та складають частку оцінки за колоквіум. Завершальним елементом інтерактивності, спрямованої на вмотивування студента до вивчення теоретичного матеріалу, є проходження колоквіуму за змістовим модулем, який також подається у тестовому форматі. Різноманіття видів тестів у середовищі Moodle LMS дозволяє побудувати таку гей міфіціровану інтерактивну систему питань, яка відображає інформацію про рівень засвоєння студентом основних термінів деякого навчального матеріалу (питання 3 множинним вибором правильної відповіді, питання на складання відповідності), розвиток індивідуальнопсихологічних властивостей студента (питання на складання певних висновків на підставі наданої інформації) та досягнення студентом рівня, який відповідає певним вимогам. При оцінюванні питань кожного типу застосовується диференційований підхід із урахуванням частки, яку серед запропонованих відповідей складають помилкові. За результатами тестування та формування підсумкової оцінки за колоквіум визначався розподіл оцінок і проводився аналіз поточної успішності експериментальної та контрольної груп. На рис. 1 наведено діаграми розподілів оцінок колоквіуму за Змістовим модулем 1 навчальної дисципліни “Теорія ймовірностей та математична статистика" у межах одного факультету двох експериментальних груп спеціальності "Міжнародна економіка" та двох контрольних груп спеціальності "Міжнародний менеджмент".

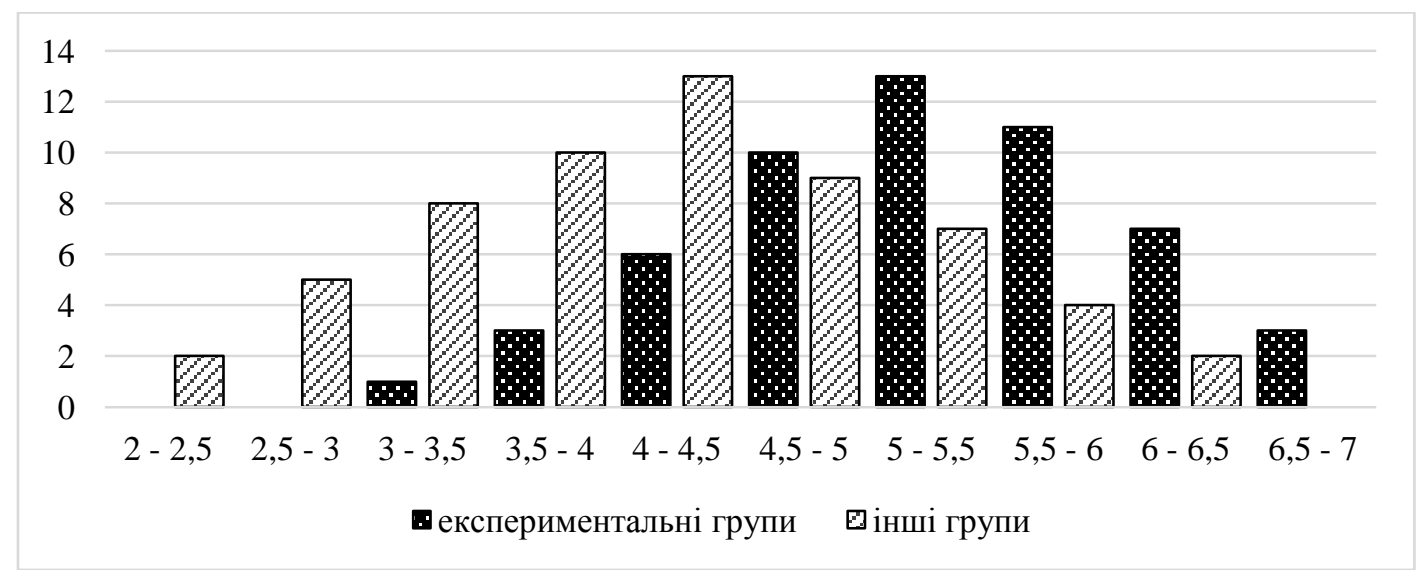

Рис. 1. Діаграми розподілів оцінок колоквіуму за Змістовим модулем 1 навчальної дисципліни "Теорія ймовірностей та математична статистика"

Аналіз результатів першого колоквіуму показав, що середній бал, який отримали студенти експериментальних груп виявився на $29 \%$ вищім, ніж у студентів тих груп, де викладання відбувалося без використання елементів інтерактивних технологій, а саме 5,3 проти 4,1 бали. За дисципліною "Прикладна математика" також спостерігався суттєвий прогрес щодо засвоєння теоретичного матеріалу. Оскільки ця дисципліна викладається лише для сту- 
дентів спеціальності "Видавництво та поліграфія", то після підведення підсуків за Змістовим модулем 1 серед студентів було проведене опитування, у якому запропоновано оцінити доцільність застосованих елементів “перевернутого" класу для навчання, рівень привабливості такої техніки, а також рівень реалізації в цих умовах власних можливостей. За підсумками анкетування встановлено, що в цілому студенти зацікавлені в проведенні занять у такому форматі та вважають використання інтерактивних технологій доцільним. Хоча в цілому результати $\epsilon$ позитивними, але студенти критично оцінили свою індивідуальну роботу.

Таким чином, проведений експеримент свідчить про ефективність використання елементів інтерактивних технологій на етапі викладання теоретичного матеріалу.

На практичних та лабораторних заняттях інтерактивним компонентом була командна робота студентів у формі експрес-опитування, мозкового штурму під час опрацювань основних методів розв'язання задач, обговорення прикладної складової завдання (розглядалися реальні економічні завдання, вирішення яких потребує використання певного математичного інструментарію). Цей етап завершувався виконанням індивідуальних домашніх завдань та лабораторних робіт, що можна розглядати як тренування перед випробуванням - контрольною роботою за кількома темами. Кожне домашне завдання складалося із багаторівневих задач, і умовою переходу на більш високий рівень було правильне виконання завдання попереднього рівня. Чим вище досягнутий студентом рівень, тим вище встановлюється бал. Завдання лабораторних робіт також мали три рівні складності, які оцінювались різними балами. Демонстрацію набутих знань i практичних навичок та вмінь інтерпретувати отримані результати здійснено за допомогою онлайн-контрольної роботи у вигляді тестів відкритого типу, завдання якої передбачали надання розгорнутої відповіді на кожному етапі розв'язання задачі. Як показник впливу інтерактивних технологій на результативність набуття практичних навичок було вибрано коефіцієнт кореляції між оцінками за контрольну роботу №1 та за виконання попередніх домашніх завдань i лабораторних робіт. У табл. 2 наведено кореляційні матриці, елементи яких визначають щільність кореляційного зв'язку між оцінками за КР №1 та попередні завдання для експериментальних групах у порівнянні 3 контрольними групами, в яких не було диференційованого підходу до вибору завдань та оцінювання результатів практичних занять i лабораторних робіт. Видно, що для контрольних груп розв'язання типових завдань не дуже сильно вплинуло на результат КР №1. Таким чином, можна стверджувати, що кореляційний зв'язок між застосуванням інтерактивних технологій на етапі навчання основним практичним методам i прийомам розв'язання математичних завдань, що мають економічне підгрунтя, $є$ суттєвим.

Таблиия 2

Кореляція між оцінками КР №1 та попередніми завданнями

\begin{tabular}{c|c|c|c|c|c|c|c|c}
\multirow{2}{*}{$\begin{array}{c}\text { Види } \\
\text { робіт }\end{array}$} & \multicolumn{4}{|c|}{ Експериментальні групи } & \multicolumn{4}{c}{ Контрольні групи } \\
\cline { 2 - 9 } Д3-1 & 1,00 & Д3-2 & ЛР №1 & КР №1 & Д3-1 & Д3-2 & ЛР №1 & КР №1 \\
\hline Д3-2 & 0,37 & 1,00 & & & 1,00 & & & \\
\hline ЛР №1 & 0,35 & 0,45 & 1,00 & & 0,17 & 1,00 & & \\
\hline КР №1 & 0,68 & 0,64 & 0,72 & 1,00 & 0,18 & 0,34 & 0,15 & 1,00 \\
\hline
\end{tabular}


Синтез набутих теоретичних та практичних знань дозволив студентам експериментальних груп виконати самостійну творчу роботу, яка полягала у написанні наукової статті або тез до конференції i підготовці доповіді, на достатньо високому рівні. Було продемонстровано здатність до використання математичних методів $\mathrm{y}$ наукових дослідженнях реальних економічних процесів і явищ.

Шостим етапом структури впровадження інтерактивних елементів до начального процесу $\epsilon$ розроблення інструментарію вмотивування студентів. 3 метою підвищення їхньої мотивації використовувалися не лише бали, а й рейтинги, які стали інструментом формування атмосфери змагання і здорової конкуренції. Досягнення успіху сприяло виробленню у студентів почуття задоволеності навчанням та вмотивовувало до нього. Завдяки налаштуванню журналу оцінок на сторінці навчального курсу в Moodle LMS кожен студент мав можливість відслідковувати статус виконання, рівень накопичення отриманих балів та власний рейтинг за кожним видом робіт. Надання інформації у такому вигляді стає для студента мотиватором i дає поштовх до подальшої активізації навчання, до пошуку шляхів закріплення та поглиблення знань.

Для дисциплін математичного спрямування завершальною стадією оцінювання ефективності запровадження елементів інтерактивних технологій до навчального процесу є складання іспиту, завдання якого за рівнем складності поділялися на три типи: діагностичні, стереотипні та евристичні. За результатами іспиту було проведено зріз аналогічний до того, який проводився на діагностичній стадії. Аналіз ефективності використаних інтерактивних засобів формування інтересу до вивчення математикних дисциплін виявив у студентів експериментальних груп позитивну динаміку щодо зміни середнього балу за іспит відносно балу за початкові знання, який було визначено на діагностичній стадії, а саме, відбулося зростання на $17 \%$ (з 72 до 84 балів). У групах, де інтерактивні елементи не застосовувалися, середній бал успішності майже не змінився. Крім цього кількісного результату, слід відзначити підвищення зацікавленості студентів до навчання, про що свідчить статистика їхньої активності на сторінці курсу.

Висновки 3 даного дослідження та перспективи подалыших розвідок у даному напрямку. Отже, для дисциплін математичного спрямування застосування елементів інтерактивних технологій у навчальному процесі виявило такі особливості:

- акцент на мотивацію - зацікавленість студентів сприяє поліпшенню якості накопичених знань, а командна робота дає позитивні емоції, які формують стійкий інтерес до пізнавального процесу;

- досягнення мети - здійснюється завдяки отриманню та поглибленню знань;

- активність студентів - ігрові інте-рактивні ситуації стають одним із найбільш ефективних засобів активізації навчального процесу;

- випробування - успішне проходження інтерактивних випробувань закріплює впевненість у своїх силах i відчуття досягнення мети;

- впевненість у собі - сумнів у власних силах 3'являється, коли студент стикається $з$ перешкодами і зазнає труднощів, але інтерактивна гра починається 3 достатньо простих випробувань, які потім поступово стають складнішими залежно від успіхів гравця;

- соціальна підтримка - аспект змагання створює необхідність системи підтримки студентів, застосування таких інтерактивних елементів, як “перевернутий” клас, що передбачало мозковий штурм при визначенні шляхів дослідження, сприяло тому, що студенти більш активно взаємодіяли, зверталися за допомогою один до одного та довикладача, 
цікавилися додатковими джерелами інформації.

Таким чином, гіпотезу про те, що для дисциплін математичного спрямування використання елементів інтерактивних технологій у навчальному процесі $\epsilon$ ефективним засобом підвищення мотивації до навчання та якості навчання в цілому, можна вважати експериментально доведеною.

У подальшому автори розглядають

\section{Список літератури:}

1. Афанасьєв М. В., Полякова Г. А., Романова Н. Ф. та ін. Тренінгове навчання в закладі вищої освіти / За заг. ред. професора М. В. Афанасьєва. - Харків: ХНЕУ ім. С. Кузнеця. - 2018. - С. 323

2. Всеукраїнський Форум "Україна 30. Освіта $i$ наука”. [електронний ресурс]. - Режим доступу: https://ukraine30.com/ educationscience/ (дата останнього звернення: 29.08.2021)

3. Гуревич Р. С., Кадемія М. Ю. Смарт-освіта - нова парадигма сучасної системи освіти / Р. С. Гуревич, М. Ю. Кадемія // Теорія i практика управління соціальними системами. 2016. - №4. C. 71-78

4. Жалдак, M. I. Педагогічний потенціал комп'ютерно-орієнтованих систем навчання математики / Жалдак М. I. // Науковий часопис НПУ імені М. П. Драгоманова, Серія 2. Комп'ютерно-орієнтовані системи навчання. - 2003. - С.3-16

5. Кабінет Міністрів України. Розпорядження від 12 червня 2019 р. № 419-р. Про схвалення Концепції реалізації державної політики у сфері професійної (професійно-технічної) освіти "Сучасна професійна (професійно-технічна) освіта" на період до 2027 року [електронний pecypc]. - Режим доступу:https://zakon. rada.gov.ua/laws/show/419-2019-\%D1\%80 \#Tехt (дата останнього звернення:19.08.21)

6. Кабінет Міністрів України. Розпорядження від 05 серпня 2020 р. № 960-р. Про схвалення Концепції роз- перспективу створення інтерактивних тренувальних вправ як ще один із елементів інтерактивних технологій, який може сприяти підвищенню ефективності вивчення дисциплін математичного спрямування, оскільки важливим $є$ не тільки наповнення навчального процесу інформаційними технологіями і ресурсами, але й врахування того, що недостатнє i несистематичне їх використання може виявитися малоефективним.

витку природничо-математичної освіти (STEM-освіти). [електронний ресурс]. Режим доступу: https://www.kmu.gov.ua/ npas/pro-shvalennya-koncepciyi-rozvitku -a960r(дата останнього звернення:19.08.21)

7. Коваль Т. І. Підготовка викладачів вищої школи: інформаційні технології у педагогічній діяльності / Т. І Коваль. - Київ: Вид. центр НЛУ 2009. - C. 380

8. Лебедєва І. Л., Норік Л. О. Ефективність e-learning студентів в умовах карантину на прикладі дисциплін математичного циклу / I. Л. Лебедєва, Л. О Норік Фізико-математична освіта. 2020. - Вип. 3(25), ч. 2. - С. 93-100

9. Мар'єнко М. В., Борисюк I. Ю. Гейміфікація освітнього процесу під час вивчення дисциплін природничо-математичного циклу учнями З3СО / М. В. Мар'єнко, І. Ю. Борисюк // Фізикоматематична освіта. - 2020. - Вип. 4(26). C. $72-78$

10. Морзе Н. В., Глазунова О. Г. Моделі ефективного використання інформаційно-комунікаційних та дистанційних технологій навчання у вищому навчальному закладі [електронний ресурс] / Н. В.Морзе, О. Г. Глазунова Інформаційні технології і засоби навчання. - 2008. 6(2). - Режим доступу: https://journal.iitta.gov. ua/index.php/itlt/article/view/138/124 (дата останнього звернення: 29.08.2021)

11. Пермінова С. О. Створення EdTech стартапів як фактор розвитку онлайн-освіти [електронний ресурс]. / С. О. Пермінова // Ефективна економіка. 
МАЙСТЕРНОСТІ МАЙБУТНІХ ФАХІВЦІВ

2021. - № 3.- Режим доступу: http://www. economy.nayka.com.ua/pdf/3_2021/84.pdf (дата останнього звернення: 19.08.2021)

12. Пометун О. І., Пироженко Л. В. Сучасний урок. Інтерактивні технології навчання / за ред. О. І. Пометун. - Київ : Видавництво А. С. К. - 2004. - С. 192

13. Семеріков С. О., Словак К. І. Теорія і методика застосування мобільних математичних середовищ у процесі навчання вищої математики студентів економічних спеціальностей [електронний ресурс] / С. О. Семеріков, К. І. Словак Інформаційні технології і засоби навчання. - 2011. - №1 (21). - Режим доступу: https://www.journal.iitta.gov.ua/index.php/ itlt/article/view/413/369 (дата останнього звернення: 29.08.2021)

14. Стратегія розвитку вищої освіти в Україні на 2021-2031 роки. - Київ: МОН -2020. - C. 71

15. Тихомиров В. П. Мир на пути Smart Education: новые возможности для развития. / В. П. Тихомиров // Открытое образование. - 2011. - № 3. - С. 22-28

16. Цілі сталого розвитку: Україна. Національна доповідь 2017 [електронний pecypc]. - Режим доступу: https://me.gov. ua/Documents/List?lang=uk-UA\&id=938 d9df1-5e8d-48cc-a007-be5bc60123b8\&tag $=$ TSiliStalogoRozvitku (дата останнього звернення: 29.08.2021)

17. Шайнер Г. I., Гавран М. I. Інформаційно-комунікаційні технології навчання іноземної мови у вищих навчальних закладах України / Г. І. Шайнер, М. І. Гавран // Інноваційна педагогіка. 2019. -Т.3. - Вип. 10. - С.128-133

18. Айхан Б. (під ред.) Цифровізація та суспільство / Б. Айхан // Франкфурт на Майні: Internationaler Verlag der Wissenschaften. - 2017. - C. 210

19. Базіл Л. Ділові ігри для менеджменту та економіки: навчання, граючи. / Базіл Л. // Всесвітня наукововидавнича компанія. - 2012. - С. 412

20. Друкер П. Ф. Посткапіталістичне суспільство / Друкер П. Ф. - НьюЙорк: Harper business. - 1993. - C. 232
21. Ринок електронного навчання: світові галузеві тенденції, частка, розмір, зростання, можливості та прогноз на 20202021 роки [електронний ресурс]. - Режим доступу:https://dna325.com/blog/e-learningmarket-global-industry-trends-share-sizegrowth-opportunity-and-forecast-2020-20 21 (дата останнього звернення: 19.08.2021)

22. 36 Компанії Edtech змінюють наш спосіб навчання [електронний pecypc]. - Режим доступу: https://builtin. com/edtech/edtech-companies останнього звернення: 19.08.2021)

23. Освітні технології: що таке EdTech? Посібник. [електронний ресурс]. Режим доступу: https://builtin.com/edtech (Last accessed: 19.08.2021)

24. Академія вчителя Europass: Перевернута класна кімната [електронний pecypc]. - Режим доступу: https://www. teacheracademy.eu/course/flippedclassroom/ (дата останнього звернення: 19.08.2021)

25. Чи EdTech формує майбутнє освіти та навчання? [електронний ресурс]. - Режим доступу:https://thescalers.com/isedtech-shaping-the-future-of-education-andlearning/(дата останнього звер-ня: 19.08.21)

26. Шваб К. Четверта промислова революція: що це означає, як реагувати. [електронний ресурс] / К. Шваб - Режим доступу: https://www.weforum.org/agenda/ 2016/01/the-fourth-industrial-revolution-

what-it-means-and-how-to-respond/ (дата останнього звернення: 19.08.2021)

27. Топ-6 платформ онлайн-навчання у світі [електронний ресурс]. Режим доступу: https://color whistle.com/ top-online-learning-platforms/

(дата останнього звернення: 19.08.2021)

28. Трюс Ю., Качала Т. Інноваційні освітні технології для підготовки 104 фахівців у технічних університетах України / Ю. Трюс, Т. Качала. - ICCER. 2013. - С. 614-621

29. Декларація тисячоліття ООН. Резолюція Генеральної Асамблеї 55/2 від 8 вересня 2000 року [електронний ресурс]. Режим доступу: https://www.ohchr.org/EN/ ProfessionalInterest/Pages/Millennium.aspx 
(дата останнього звернення: 19.08.2021)

30. Вербах, К., Хантер, Д. За перемогу, переглянуте та оновлене видання: Сила гейміфікації та ігрового мислення у бізнесі, освіті, уряді та соціальному впливі / К. Вербах, Д. Хантер. - Пенсільванія: Wharton School Press. 2020. - C. 152

31. Всесвітній економічний форум. Звіт Insight: Звіт про глобальну конкурентоспроможність за 2019 рік. [електронний ресурс]. - Режим доступу: http://www3.weforum.org/docs/WEF_The GlobalCompetitivenessReport2019.pdf (дата останнього звернення: 19.08.2021)

\section{References:}

1. Afanas'iev, M. V.,Poliakova, H. A., Romanova, N. F. and other (2018) "Training in a higher education institution", For general. ed. professor M. V. Afanas'ieva, Kharkiv: S. Kuznets KNUE, p. 323

2. All-Ukrainian Forum "Ukraine 30. Education and Science", available at: https://ukraine30.com/education_science/ (Last accessed: 29.08.2021)

3. Gurevych, R. S., Kademiya, M. Yu. (2016) "Smart-education - a new paradigm of modern education system", Theory and practice of social systems management, no 4, pp. $71-78$

4. Zhaldak, M. I. (2003). "Pedagogical potential of computer-oriented mathematics teaching systems", Scientific journal of NPU named after MP Drahomanov, series 2, Computer training systems, pp. 3-16

5. Cabinet of Ministers of Ukraine. Order of June 12, 2019 № 419-r. “About approval of the Concept of realization of the state policy in the field of professional (vocational) education", Modern professsional (vocational) education" for the period till 2027", available at: https://zakon.rada. gov.ua/laws/show/419-2019-\%D1\%80\#Text (Last accessed: 19.08.2021)

6. Cabinet of Ministers of Ukraine. Order of August 5, 2020 № 960-r. "About approval of the Concept of development of natural and mathematical education (STEMeducation)", available at: https://www.kmu. gov.ua/npas/pro-shvalennya-koncepciyirozvitku-a960r (Last accessed: 19.08.2021)

7. Koval, T. I. (2009), "Training of higher school teachers: information technologies in pedagogical activity", Kyiv: Vyd. tsentr NLU, p.380

8. Lebedeva, I. L., Norik, L. O. (2020), “The effectiveness of e-learning students inquarantine on the example of the disciplines of the mathematical cycle", Physical \& mathematical education, issue 3 (25), part 2, pp. 93-100

9. Marienko, M. V., Borysiuk I. Yu. (2020), "Gamification of the educational process during the study of disciplines of the natural and mathematical cycle by pupils of IGSE", Physical \& mathematical education, issue 4(26), pp.72-78

10. Morze, N. V., Hlazunova, O. H. (2008), "Models of effective use of information and communication and distance learning technologies in higher education", Information Technologies and Learning tools. 6(2), available at: https://journal.iitta.gov.ua/ index.php/itlt/article/view/138/124 (Last accessed: 29.08.2021)

11. Perminova, S. O. (2021), "Creating of EdTech startups as a factor in the development of online education". Efficient economy, no 3, available at: http://www.eco nomy.nayka.com.ua/pdf/3_2021/84.pdf (Last accessed: 19.08.2021)

12. Pometun, O. I., Pyrozhenko, 1. V. (2004), "A modern lesson. Interactive learning technologies", for ed. O. I. Pometun, Kyiv: Vydavnytstvo A.C.K, p.192

13. Semerikov, S. O., Slovak, K. I. (2011), "Theory and methods of application of mobile mathematical environments in the process of teaching higher mathematics to students of economic specialties", Information Technologies and Learning Tools, no 1 (21), available at: https://www.journal. iitta.gov.ua/index.php/itlt/article/view/413/36 9 (Last accessed: 29.08.2021)

14. "Strategy for the development of higher education in Ukraine for 2021-2031", 
МАЙСТЕРНОСТІ МАЙБУТНІХ ФАХІВЦІВ

(2020), Kyiv: MES, p. 71

15. Tihomirov, V. P. (2011) "The world on the way to Smart Education: new opportunities for development", Open education, no 3. pp. 22-28

16. "Sustainable development goals: Ukraine. National report 2017”, available at: https://me.gov.ua/Documents/List?lang=ukU A\&id=938d9df1-5e8d-48cc-a007be5bc60 123b8\&tag=TSiliStalogoRozvitku (Last accessed: 29.08.2021)

17. Shainer, H. I., Havran, M. I. (2019), "Information and communication technologies of foreign language teaching in higher educational institutions of Ukraine", Innovative pedagogy, v.3. issue, 10, pp128-133

18. Ayhan, B. (2017), "Digitalization and society", Frankfurt am Main: Internationaler Verlag der Wissenschaften, p. 210

19. Bazil, L. (2012), "Business Games for Management and Economics: Learning by Playing", World Scientific Publishing Company, p. 412

20. Drucker, P. F. (1993) "Postcapitalist society", New York: Harper business, p. 232

21. "E-learning market: global industry trends, share, size, growth, opportunity and forecast 2020-202", available at: $\quad$ https://dna325.com/blog/e-learningmarket-global-industry-trends-share-sizegrowth-opportunity-and-forecast-2020-2021/ (Last accessed: 19.08.2021)

22. "36 Edtech companies changing the way we learn", available at: https://builtin.com/edtech/edtech-companies (Last accessed: 19.08.2021)

23. "Education Technology: What Is EdTech? A Guide", available at: https:// builtin.com/edtech (Last accessed: 19.08.2021)
24. "Europass Teacher Academy: Flipped Classroom", available at: https://www.teacheracademy.eu/course/flippe d-classroom/ (Last accessed: 19.08.2021)

25. "Is EdTech shaping the future of education and learning?", available at: https:// thescalers.com/is-edtech-shaping-the-futureof-education-and-learning/ (Last accessed: 19.08.2021)

26. Schwab, K. "The Fourth Industrial Revolution: what it means, how to respond", available at: https://www.weforum.org/agen $\mathrm{da} / 2016 / 01 /$ the-fourth-industrial-revolutionwhat-it-means-and-how-to-respond/ (Last accessed: 19.08.2021)

27. "Top 6 Online Learning Platforms in the World", available at: https://color whistle.com/top-online-learning-platforms/ (Last accessed: 19.08.2021)

28. Tryus, Yu., Kachala, T. (2013), "Innovation education technologies in training of 104IT professionals in the Technical Universities in Ukraine" ICCER, pp. 614-621

29. "United Nations Millennium Declaration. General Assembly resolution $55 / 2$ of 8 September 2000", available at: https://www.ohchr.org/EN/ProfessionalIntere st/Pages/Millennium.aspx (Last accessed: 19.08.2021)

30. Werbach, K., Hunter, D. (2020), "For the Win, Revised and Updated Edition: The Power of Gamification and Game Thinking in Business, Education, Government, and Social Impact", Pennsylvania: Wharton School Press, p. 152

31. "World Economic Forum. Insight report: The global competitiveness report 2019”, available at: http://www3.weforum. org/docs/WEF_TheGlobalCompetitivenessRe port2019.pdf (Last accessed: 19.08.2021) 